\title{
Effects of Concrete Mulch on Soil Thermal and Moisture Regimes
}

\author{
Yuping LeI*, Hidenori TAKAHASHI** and Weiqiang Li*
}

$\left(\begin{array}{c}* \text { Shijiazhuang Institute of Agricultural Modernization, CAS, Shijiazhuang, 050021 China } \\ * * \text { Graduate School of Environmental Earth Sciences, Hokkaido University, Sapporo, 060-0810 Japan }\end{array}\right)$

\begin{abstract}
Although concrete mulch hasn't been used widely for agriculture, it is advantageous for conserving soil water because concrete forms a surface without gaps and can limit evaporation and retain water. A jujube (Ziziphus jujube Mill.) field experiment and a lysimeter-plot experiment were carried out in this study to evaluate the hydrothermal properties of concrete mulch by comparing the differences in surface energy balance, surface temperature and soil moisture and temperature between the mulched and bare soils. The rate of evaporation from the mulched lysimeter-plot was about $0.04 \mathrm{~mm}$ per day, whereas it was $1.74 \mathrm{~mm}$ from the bare lysimeter-plot in September. During the freezing/thawing period (December to February), the soil moisture in the surface $10 \mathrm{~cm}$ layer increased by $0.030 \mathrm{~g} \mathrm{~g}^{-1}$ in the mulched jujube plot, whereas it decreased by $0.032 \mathrm{~g} \mathrm{~g}^{-1}$ in the bare jujube plot. Daytime net radiation at the concrete surface was lower than that at the bare soil surface; however, the heat flux into mulch layer was higher than into bare soil when bare soil moisture was rather high. The surface temperature of concrete mulch rose as high as $57^{\circ} \mathrm{C}$ and was about $10^{\circ} \mathrm{C}$ higher than that of bare soil in summer, but it was moderate under a tree canopy. The mulched soil temperatures at 5 and $10 \mathrm{~cm}$ depth were higher by about $2^{\circ} \mathrm{C}$ than those for bare soil during the night in summer and winter.
\end{abstract}

Key words: Concrete mulch, Soil moisture, Soil temperature, Surface energy balance, Surface temperature.

\section{Introduction}

Organic mulch and plastic mulch have generally been used in crop and fruit tree fields in order to moderate soil temperature, and conserve soil moisture and nutrients (Iiles and Dosmann, 1999). Mineral mulch has mainly been used to conserve soil water in arid or semi-arid areas, because materials such as stone, gravel and rock can effectively reduce water evaporation from soil surface and control weeds (Gale et al., 1993; Jury and Bellantuoni, 1976; Mellouli et al., 2000; Nachtergaele et al., 1998). Concrete has similar thermal properties to stone, gravel and rock. Although it is a familiar scene that urban tree roots are mulched or constrained by concrete, there has been little research on concrete mulch. Since 1994, concrete mulch has been tested as a cultivation technique of water-saving agriculture on the North China Plain, where irrigation consumes over $75 \%$ of the total water use $(\mathrm{Li}$

Received on March 23, 2001.

Accepted on November 20, 2003. and Tschirley, 1997). Water-shortage has become so serious that an extremely expensive project to divert water from the Yangtze in southern China to the North China Plain is currently being planned. In a previous study, we reported that concrete mulch could enhance the growth of jujube trees, increase jujube yield and prevent soil salt from accumulating in the surface layer in a jujube orchard ( $\mathrm{Li}$ et al., 2000). In the present study, we investigated the effects of concrete mulch on surface energy balance, surface temperature and soil moisture and temperature by comparing the differences between the mulched and unmulched soils.

\section{Materials and Methods}

This study was conducted at Nanpi Agroecological Experimental Station $\left(38^{\circ} 07^{\prime} \mathrm{N}, 116^{\circ} 45^{\prime} \mathrm{E}\right)$, Chinese Academy of Sciences, located in the Heilonggang region of Hebei Province, China. At the site, the 20-year annual average precipitation was $470 \mathrm{~mm}$ with more than $70 \%$ of rainfall occurring during July and August and air temperature was 
$12.3^{\circ} \mathrm{C}$. The tested soil was a desalinized loam. Concrete used in the study was a mix of one part of Portland cement with three parts of sand. The density of the concrete was about $2,100 \mathrm{~kg} \mathrm{~m}^{-3}$ and the calculated thermal diffusivity about $0.5 \times 10^{-6} \mathrm{~m}^{2}$ $\mathrm{s}^{-1}$.

A jujube field experiment and a lysimeter experiment, each including a treatment of concrete mulch and a control of bare soil (no mulching), were carried out to evaluate the mulch effects on soil hydrothermal regimes with or without plant growth.

\subsection{Jujube field experiment}

One of two plots $(16 \mathrm{~m} \times 8 \mathrm{~m})$ in a Chinese jujube (Ziziphus jujube Mill.) orchard ( $2 \mathrm{~m}$ tree space and 1 $\mathrm{m}$ between rows) was covered using $2-3 \mathrm{~cm}$ thick concrete as a mulching treatment field (Fig. 1(a)), and the other was unmulched as a bare control field in April 1994. Soil moisture at a depth of $0-100 \mathrm{~cm}$ in the plots was measured using a gravimetric method about every 20 days from April 1998 to March 1999. Soil moisture $\left(\mathrm{g} \mathrm{g}^{-1}\right)$ was derived as \{(weight of wet soil-weight of dry soil)/weight of dry soil\}. Surface temperature was measured using a thermister thermometer and an infrared spot thermometer (Minolta Co., Model HT-11) and short-

(a) Field Experiment

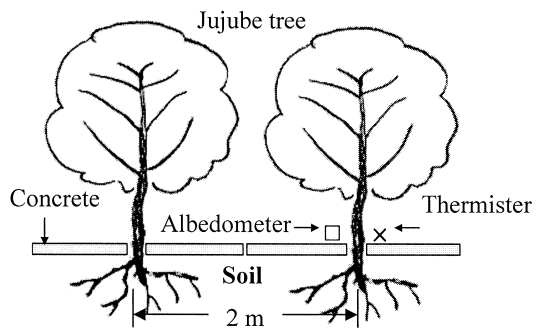

(b) Lysimeter plot Experiment

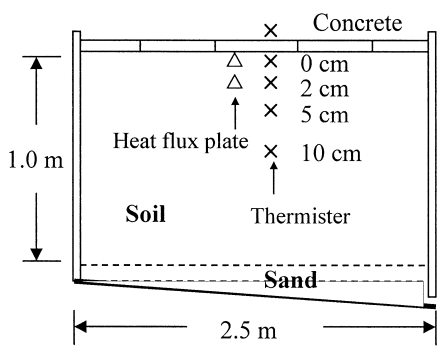

Fig. 1. Schematics of the mulching treatment set-ups in the two experiments. wave radiation at the surface was measured using an albedometer (PREDE Co., Model-PCM-01) in May and June 1999.

\subsection{Lysimeter experiment}

A lysimeter facility consisting of six concrete plots ( $3 \mathrm{~m}$ in length, $2.5 \mathrm{~m}$ in width and $1.2 \mathrm{~m}$ in depth for each plot) filled with soil $1 \mathrm{~m}$ deep was used in this experiment (Fig. 1(b)). Four plots were sealed using the concrete plates and represented a mulching treatment, and two plots were unmulched and represented a bare control in November 1998. The concrete plate had a width and length of $50 \mathrm{~cm}$ and thickness of $1.5 \mathrm{~cm}$ with an iron wire netting $(5 \mathrm{~cm}$ $\times 5 \mathrm{~cm}$ cell) in the middle of the plate. Surface temperatures and soil temperature at 2,5 and $10 \mathrm{~cm}$ in depth were measured using an infrared thermometer (Minolta Co., Model HT-11) and thermister thermometer. The heat fluxes at 0 and $2 \mathrm{~cm}$ in depth were measured using a heat flux plate (OKI Co., Model-MF-81) at 10-min intervals and soil moisture was monitored by sampling soil at $5 \mathrm{~cm}$ intervals from September 1 to 9, 1999. Albedos of the concrete plate and bare soil were measured using an albedometer. A method for simulating surface energy balance (van Bavel and Hillel, 1976) was used to calculate the partition of energy budget at the surfaces of concrete and bare soil, and measured surface temperature, albedo, soil heat flux and daily total amount of evaporation were used as inputted values. A meteorology station at the experiment station provided hourly average air temperature, relative humidity, solar radiation and wind speed.

\section{Results and Discussion}

\subsection{Effect on soil moisture}

Soil moistures in mulched and bare lysimeter-plots at the beginning of winter (December 7) and at the end of winter (February 25) are shown in Fig. 2. From December 7 to February 25, average soil moisture in the bare plot decreased by $0.026 \mathrm{~g} \mathrm{~g}^{-1}$ while that in the mulched plot by less than $0.001 \mathrm{~g} \mathrm{~g}^{-1}$. In winter, when soil temperature in upper layer was lower than that in lower layer, liquid or vapor water moved to the upper soil horizon from the lower horizon induced by temperature gradients and accumulated at the freezing front in the upper horizon by forming ice (Hillel, 1980). Figure 4(a) shows the mean air temperatures in the experimental site were below zero during late December to late January; 


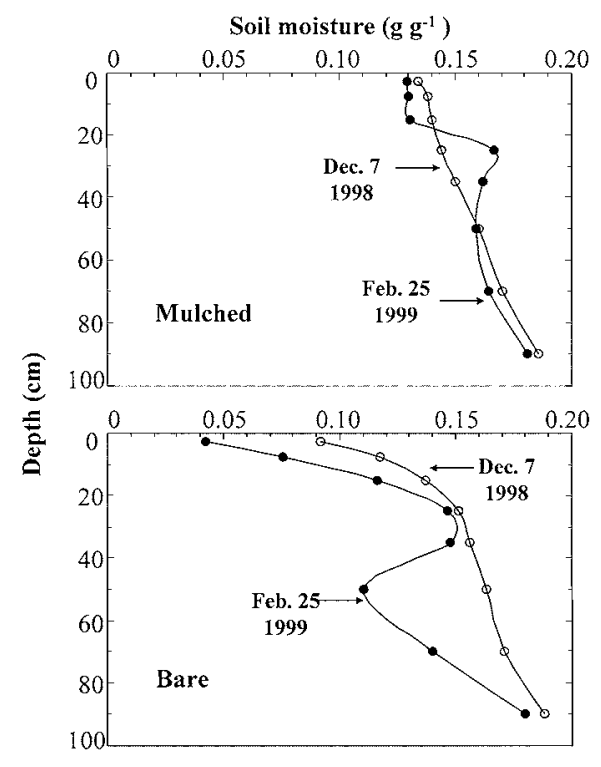

Fig. 2. Soilust moisture changes in mulched and bare lysimeter-plots in winter (December 7, 1998 to February 25, 1999).

therefore soil started freezing in late December and thawing in late January. The redistribution of soil moisture in lysimeter-plots could be caused by the moisture accumulation during freezing and diffusion during thawing (Fig. 2). Figure 2 shows that moisture accumulation occurred at $20-40 \mathrm{~cm}$ depth in both mulched and bare lysimeter-plots, but because the total amount of evaporation from the bare plot $(26.4 \mathrm{~mm})$ was much higher than from the mulched plot $(0.5 \mathrm{~mm})$, the soil moistures at $0-20 \mathrm{~cm}$ and $40^{-}$ $80 \mathrm{~cm}$ in depth decreased by 0.046 and $0.042 \mathrm{~g} \mathrm{~g}^{-1}$, respectively, in the bare lysimeter-plot, while soil moistures at the two depths by less than $0.010 \mathrm{~g} \mathrm{~g}^{-1}$ in the mulched plot.

Daily soil moistures (sampled at 18:00-18: 30 ) in mulched and bare lysimeters plots during September 2 to September 9 are shown in Fig. 3. Moistures at 0 $-5 \mathrm{~cm}$, and $5-10 \mathrm{~cm}$ depth in the bare plot decreased about 0.088 , and $0.046 \mathrm{~g} \mathrm{~g}^{-1}$, respectively, while the moisture in the mulched plot decreased about 0.002 $\mathrm{g} \mathrm{g}^{-1}$ at the $0-5 \mathrm{~cm}$ in depth. Estimated according to the difference in soil moistures at the depth of 0-30 $\mathrm{cm}$ between day September 2 and September 9, the mean evaporation rate was about $1.74 \mathrm{~mm}$ per day in the bare plot, while that in the mulched plot only $0.04 \mathrm{~mm}$.

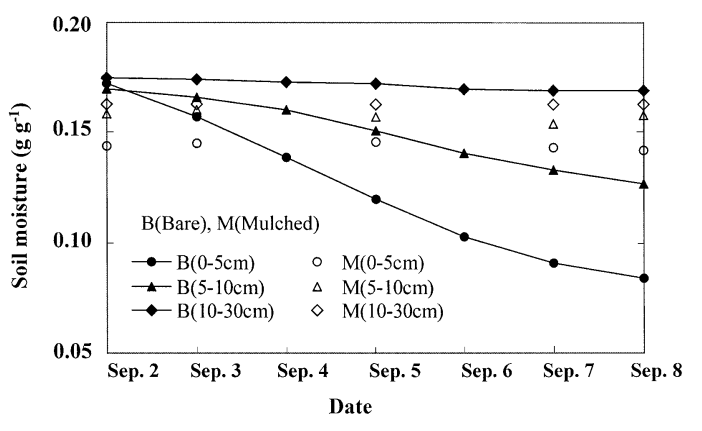

Fig. 3. Daily changes of soil moisture in mulched and bare lysimeter-plots in autumn (September 2 to September 8, 1999).

The main difference in soil moisture between the mulched and bare jujube plots was in the surface 40 $\mathrm{cm}$ layer (data not shown), and the difference in the 0-10 cm layer was the most significant (Fig. 4). During September 5 to October 11, with a daily mean air temperature of about $24^{\circ} \mathrm{C}$, the soil moisture contents in the $0-10 \mathrm{~cm}$ layer decreased by 0.036 $\mathrm{g} \mathrm{g}^{-1}$ in the mulched jujube plot due to transpiration, and by $0.093 \mathrm{~g} \mathrm{~g}^{-1}$ in the bare jujube plot due to evapotranspiration. After fruit harvest at the beginning of October, the soil moisture decreased by 0.005 $\mathrm{g} \mathrm{g}^{-1}$ in the mulched jujube plot during October 11 to November 5, while it increased by $0.029 \mathrm{~g} \mathrm{~g}^{-1}$ in the bare plot because of the rainfall of $19.5 \mathrm{~mm}$ in that period. In the mulched jujube plot, the rainfall was intercepted by the concrete surface. When the rainfall was large enough to form a runoff, rainwater flowed into the soil through the bare soil around the tree trunk and slots in the mulch surface. During the freezing/thawing period (December to February), the soil moisture content increased by about $0.032 \mathrm{~g}$ $\mathrm{g}^{-1}$ in the mulched jujube plot but decreased by about $0.030 \mathrm{gg}^{-1}$ in the bare jujube plot due to evaporation (Fig. 4).

Organic mulch, such as straw mulch, reduces evaporation by decreasing the amount of radiant energy absorbed and minimizing air flow at the soil surface, and the efficiency is restricted on a long term view (Mellouli et al., 2000). Mineral mulch is impervious to water vapor and is thus expected to conserve soil water more efficiently than organic mulch. However, in previous studies, Iiles and Dosmann (1999) showed that the efficiency of conserving soil moisture by mulches of gravel, crushed brick and rocks was 
significant but not higher than organic mulches, and Nachtergaele et al. (1998) showed gravel mulch in fact increased the evaporation rate compared to bare soil. Since the sizes of the mulch material used in their studies were relative small, evaporation could have occurred through gaps in the mulch layer, and the relatively high temperature of the mulch could have enhanced the evaporation. In comparison with natural materials, a mulch layer without any gap can easily be formed using concrete, and is therefore a very efficient means for conserving water in a field.

\subsection{Effect on surface energy balance and tempera- ture}

Mulch primarily affects a field microclimate by changing the surface radiation budget. Table 1 shows that daytime $(8: 00-17: 00 \mathrm{~h})$ total net radiation $\left(R_{\mathrm{n}}\right)$ at the surface of the mulched lysimeter-plot was lower than at the bare soil surface by about $0.15 R_{\mathrm{s}}\left(1.27 \mathrm{MJ} \mathrm{m}^{-2}\right)$ on a day with low solar radia- tion day (September 3$)$ and by about $0.12 R_{\mathrm{s}}(1.73$ $\mathrm{MJ} \mathrm{m}^{-2}$ ) on a day with high radiation day (September 8$)$, mainly due to higher albedo of the concrete surface $(0.25-0.28$ for concrete and $0.13-0.16$ for bare soil). Besides of higher albedo, the higher surface temperatures of concrete was a second factor lowering $R_{\mathrm{n}}$. Table 1 shows that $R_{\mathrm{n}}$ at the mulch surface was partitioned into $G$ (mulch) and $H$, whereas that at the bare soil surface into $L E, G$ (bare soil) and $H$. The differences in daytime heat fluxes between mulch and bare soil surfaces were significantly affected by soil moisture in the bare plot. While soil moisture at surface $5 \mathrm{~cm}$ was larger than $0.15 \mathrm{~g} \mathrm{~g}^{-1}$ in the bare plot on September 3 (Fig. 3), and $L E$ consumed $53 \%$ of $R_{\mathrm{n}}$ at the bare soil surface, $G$ (mulch) was higher than $G$ (bare soil) by $0.38 R_{\mathrm{s}}$ $\left(1.9 \mathrm{MJ} \mathrm{m}^{-2}\right)$ (Table 1). However, when the soil moisture at surface $5 \mathrm{~cm}$ decreased to $0.08 \mathrm{~g} \mathrm{~g}^{-1}$ on September 8 , though $R_{\mathrm{s}}$ on September 8 was larger

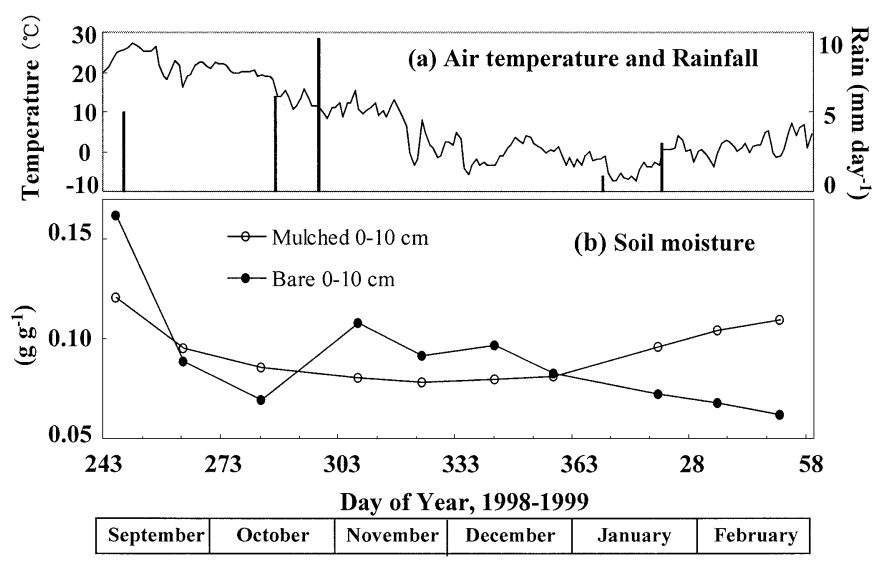

Fig. 4. Effect of concrete mulch on soil moisture in the jujube plot during dry and cold period (September, 1998 to February, 1999). (a) Daily average air temperature, rainfall and (b) soil moisture at $10 \mathrm{~cm}$ depth in the mulched and bare jujube plots.

Table 1. Total daytime (8:00-17:00 h) energy fluxes at the surfaces of the mulched and the bare lysimeter-plots on September 3 and September 8.

\begin{tabular}{|c|c|c|c|c|}
\hline \multirow{2}{*}{$\begin{array}{l}\text { Energy flux } \\
\left(\mathrm{MJ} \mathrm{m}^{2}\right)\end{array}$} & \multicolumn{2}{|c|}{ Sep. 3} & \multicolumn{2}{|c|}{ Sep. 8} \\
\hline & Mulched & Bare (wet) & Mulched & Bare (dry) \\
\hline$R_{\mathrm{s}}$ & 9.19 & 9.19 & 14.7 & 14.7 \\
\hline$R_{\mathrm{n}}$ & $5.88\left(0.64 R_{\mathrm{s}}\right)$ & $7.25\left(0.79 R_{\mathrm{s}}\right)$ & $9.16\left(0.62 R_{\mathrm{s}}\right)$ & $10.86\left(0.74 R_{\mathrm{s}}\right)$ \\
\hline$G$ & $-3.50\left(0.60 R_{\mathrm{n}}\right)$ & $-1.60\left(0.22 R_{\mathrm{n}}\right)$ & $-4.02\left(0.44 R_{\mathrm{n}}\right)$ & $-3.92\left(0.31 R_{\mathrm{n}}\right)$ \\
\hline$H$ & $-2.37\left(0.40 R_{\mathrm{n}}\right)$ & $-1.81\left(0.25 R_{\mathrm{n}}\right)$ & $-5.13\left(0.56 R_{\mathrm{n}}\right)$ & $-4.86\left(0.50 R_{\mathrm{n}}\right)$ \\
\hline$L E$ & 0 & $-3.84\left(0.53 R_{\mathrm{n}}\right)$ & 0 & $-2.08\left(0.19 R_{\mathrm{n}}\right)$ \\
\hline
\end{tabular}

$R_{\mathrm{s}}=$ solar radiation, $R_{\mathrm{n}}=$ net radiation, $G($ mulch $)=$ mulch heat, $G($ bare $)=$ bare soil heat, $H=$ sensible heat, $L E=$ latent heat, and negative values represent direction away from the surface while the positive toward the surface. 
than on September 3 by about $50 \%, L E$ consumed only $19 \%$ of $R_{\mathrm{n}}$ at the bare soil surface; therefore the difference between $G$ (mulch) and $G$ (bare soil) was only $0.01 R_{\mathrm{s}}\left(0.13 \mathrm{MJ} \mathrm{m}^{-2}\right)$ and was much smaller than that on September 3 (Table 1). For the concrete mulch surface, while $R_{\mathrm{n}}$ on September 8 was higher by $3.28 \mathrm{MJ} \mathrm{m}^{-2}$ than on September 3, $84 \%$ of the increase $R_{\mathrm{n}}$ was consumed by $H\left(2.76 \mathrm{MJ} \mathrm{m}^{-2}\right)$, and $G$ consumed only $16 \%\left(0.52 \mathrm{MJ} \mathrm{m}^{-2}\right)$.

Since no energy was used for evaporation at the mulch surface and dry concrete has a relatively low specific heat (about $0.7 \mathrm{Jg}^{-1} \mathrm{~K}^{-1}$ ), the maximum surface temperature of mulch rose as high as $57^{\circ} \mathrm{C}$ and was about $10^{\circ} \mathrm{C}$ higher than that of bare soil in summer (Fig. 5). The high surface temperature of mineral mulch is considered to cause damage to young plants and shallow-rooted species (Iiles and Dosmann, 1999). However, the regime of the surface temperature is affected by the amount of solar radiation reaching the surface as well as by surface properties. When the daytime $(8: 00-18: 00 \mathrm{~h}) R_{\mathrm{s}}$ was about $4.5 \mathrm{MJ} \mathrm{m}^{-2}$ in the jujube plot under a canopy, the maximum surface temperature in the mulched jujube plot was about $20^{\circ} \mathrm{C}$ lower than in the mulched lysimeter-plot, where the value of $R_{\mathrm{s}}$ was $15.3 \mathrm{MJ} \mathrm{m}^{-2}$ (Table 2). The differences in the maximum and mean surface temperature between the mulched and bare jujube plots were $2.0^{\circ} \mathrm{C}$ and $2.5^{\circ} \mathrm{C}$, respectively, and were much smaller than the differences between the two lysimeter-plots $\left(12.1^{\circ} \mathrm{C}\right.$ and $8.1^{\circ} \mathrm{C}$ ). The crop seeded in summer may be damaged by the high surface temperature of concrete mulch before its canopy has developed.

\section{3 Effect on soil temperature}

In contrast with surface temperature, the difference in soil temperature between the mulched and bare lysimeter-plots occurred mainly during the nighttime in summer (Fig. 5). The soil temperatures at $5 \mathrm{~cm}$ and $10 \mathrm{~cm}$ depth in the mulched lysimeterplot were higher than in the bare lysimeter-plot by $2.8^{\circ} \mathrm{C}(16: 00-6: 00 \mathrm{~h})$ and $2.1^{\circ} \mathrm{C}(18: 00-8: 00 \mathrm{~h})$, respectively. The same pattern was observed in autumn, but the difference was smaller. In winter,

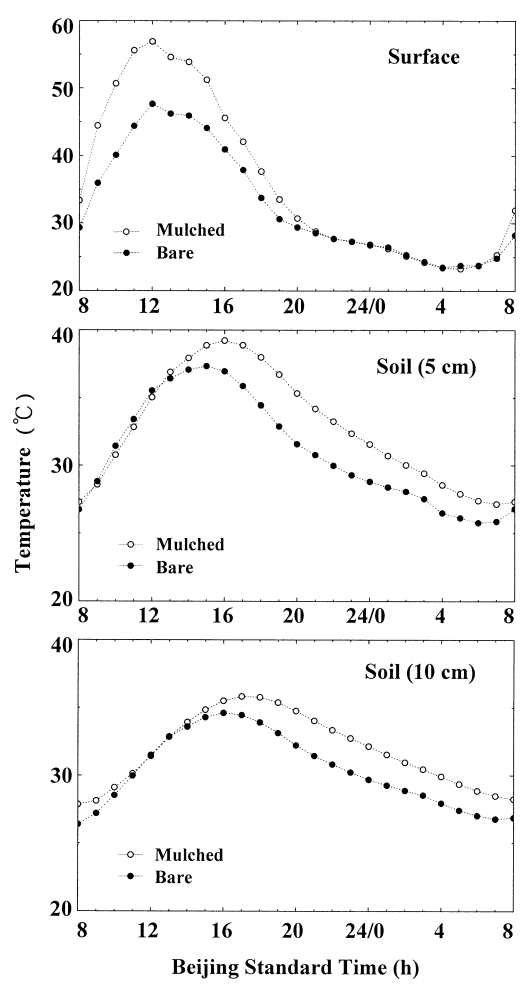

Fig. 5. Surface temperatures and soil temperatures at $5 \mathrm{~cm}$ and $10 \mathrm{~cm}$ depth in the mulched and bare lysimeter-plots in summer (August 2-3, 1999).

Table 2. Daytime (8:00-17:00 h) surface temperatures in the mulched and bare jujube plots (low shortwave radiation) and lysimeter-plots (high shortwave radiation).

\begin{tabular}{lccccc}
\hline \multirow{2}{*}{ Surface conditions } & \multicolumn{2}{c}{ Orchard (May 14) } & & \multicolumn{2}{c}{ Lysimeter (May 14) } \\
\cline { 2 - 3 } \cline { 5 - 6 } & Mulched & Bare & & Mulched & Bare \\
\hline$\theta\left(\mathrm{g} \mathrm{g}^{-1}\right)$ & - & 0.134 & & - & 0.126 \\
$R_{\mathrm{s}}\left(\mathrm{MJ} \mathrm{m}^{-2}\right)$ & 4.50 & 4.29 & & 15.30 & 15.30 \\
Surface temperature $\left({ }^{\circ} \mathrm{C}\right)$ & & & & \\
$\quad$ Mean & 27.8 & 25.3 & & 44.4 & 36.3 \\
$\quad$ Maximum & 35.1 & 33.2 & & 54.1 & 42.2 \\
$\quad$ Minimum & 20.4 & 19.7 & & 31.0 & 27.3 \\
\hline
\end{tabular}

$\theta=$ soil moisture of surface $2 \mathrm{~cm}, R_{\mathrm{s}}=$ shortwave radiation at surface. 


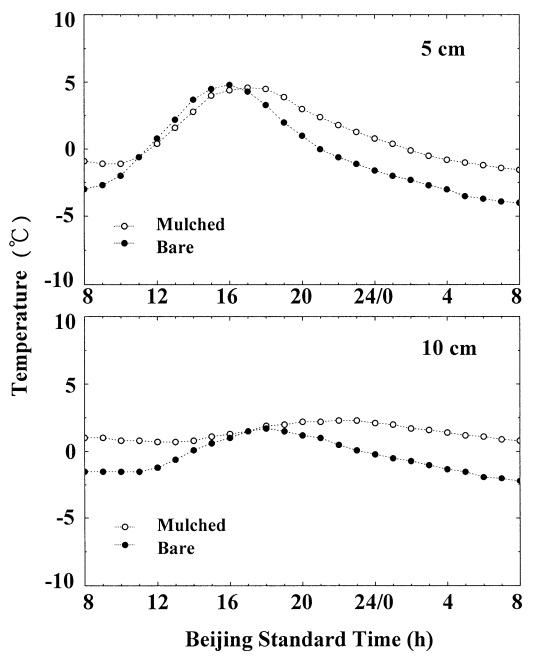

Fig. 6. Soil temperatures at 5 and $10 \mathrm{~cm}$ depth in mulched and bare lysimeter-plots in winter (January 27-28, 1999).

when the daily air temperature varied from -6 to $8^{\circ} \mathrm{C}$, with a mean value of $-0.6^{\circ} \mathrm{C}$, the daily soil temperatures at $5 \mathrm{~cm}$ and $10 \mathrm{~cm}$ in depth in the mulched lysimeter-plot were higher than those in the bare lysimeter-plot by $1.4^{\circ} \mathrm{C}$ and $1.8^{\circ} \mathrm{C}$, respectively, and the nighttime (20:00-6:00 h) soil temperatures in the mulched lysimeter-plots were higher by $2.3^{\circ} \mathrm{C}$ and $2.4^{\circ} \mathrm{C}$, respectively (Fig. 6). Jujube tree under concrete mulch sprouted about 7 days earlier than those in the bare plot during 1996 to 1999 (Li et al., 2000). Concerning jujube leaves falling in autumn, the effects of concrete mulch on thermal regime in the tree plot was comparable to conditions in the lysimeter-plot in early spring; therefore the higher surface temperature and soil temperature can be a factor promoting tree growth.

The mulch affected the soil thermal regime by modifying surface energy balance; on the other hand, the moisture regime may dominate the thermal regime by changing thermal conductivity and soil heat capacity. Figure 7 shows the positive differences in soil temperatures around noon between the mulched and bare lysimeter-plots in the upper soil layer becoming gradually smaller in response to the drying process of soil in the bare plot during September 4 to September 7 (Fig. 3). In particular, the difference at $2 \mathrm{~cm}$ around noon decreased to near $-2^{\circ} \mathrm{C}$ on September 7 from about $0.3^{\circ} \mathrm{C}$ on Septem-

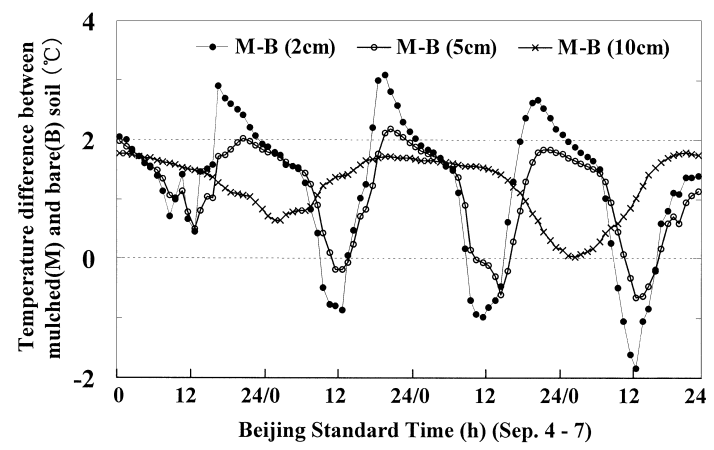

Fig. 7. Differences (Temperature $\mathrm{M}$ minus Temperature B) in soil temperature at 2, 5 and $10 \mathrm{~cm}$ depth between mulched (M) and bare (B) lysimeter-plots during September 4 to September 7.

ber 4 (Fig. 7) because of the significant reduction in soil heat capacity and thermal conductivity with decreasing soil moisture by $0.086 \mathrm{~g} \mathrm{~g}^{-1}$ at $0-5 \mathrm{~cm}$ in depth in the bare plot (Fig. 3).

\section{Conclusions}

The net radiation at the surface of concrete mulch was lower than that at the bare soil surface, but daytime mulch heat flux could be significantly higher than bare soil heat flux while bare soil moisture was rather high. The maximum surface temperature of mulch was almost $60^{\circ} \mathrm{C}$ and was significantly higher than that of bare soil in summer; however the surface temperature of mulch below a canopy was moderate and similar to that of bare soil. The concrete mulch increased the soil temperature in the surface $10 \mathrm{~cm}$ layer by about $2^{\circ} \mathrm{C}$ during the nighttime in summer and winter, but the difference in daytime soil temperature in the surface layer was affected by the soil moisture regime. Concrete mulch enabled efficient conservation of soil water by stopping evaporation of soil moisture to the atmosphere; therefore it can provide a persistent mulch for dryland or rainfed farming, especially in places where soil needs to be protected from erosion.

\section{Acknowledgements}

This study was supported by a Grant-in-Aid for Creative Basic Research (No. 09NP0901) from the Ministry of Education, Culture, Sports, Science and Technology, Japan. We would like to thank the staff 
of Nanpi Agro-ecological Experimental Station, Shijiazhuang Institute of Agricultural Modernization, CAS for their technical support.

\section{References}

Gale, W. J., Mc Coll, R. W. and Fang, X., 1993: Sandy fields traditional farming for water conservation in China. J. Soil Water Cons., 48, 474-477.

Hillel, D., 1980: Applications in soil physics. Academic Press, Inc., New York, pp. 254-299.

Iiles, J. K. and Dosmann, M.S., 1999: Effect of organic and mineral mulches on soil properties and growth of FAIRVIEW FLAME RED MAPLE TREES. J. Arbori., 25 (3), 163-167.

Jury, W. A. and Bellantuoni, B., 1976: Heat and water movement under surface rocks in a field soil: I. Thermal effects and II. Moisture effects. Soil Sci. Soc. Am. J., 40, 505-513.

Li, W., Zhang, X., Lei, Y., Tian, Q. and Okazaki, M., 2000: Effect of concrete mulching on the movement of soil water and salt and growth of jujube. Eco-Agric. Res., 8 (3), 51-54 (in Chinese with English abstract).

Li, X. and Tschirley, J. B., 1997: Sustainable agriculture and rural development in China. Sustainable Development Department, FAO. (http://www. fao.org/sd/EPdirect/EPan0009.htm)

Mellouli, H. J., Wesemael, B. van, Poesen, J. and Hartmann, R., 2000: Evaporation losses from bare soils as influenced by cultivation techniques in semi-arid regions. Agric. Water Manage., 42, 355-369.

Nachtergaele, J., Poesen, J. and Wesemael, B. van, 1998: Gravel mulching in vineyards of southern Switzerland. Soil Tillage Res., 46, 51-59.

van Bavel, C. H. M. and Hillel, D. I., 1976: Calculating potential and actual evaporation from a bare soil surface by simulation of concurrent flow of water and heat. Agric. Meteorol., 17, 453-476.

\section{地温および土壤水分におよぼす コンクリートマルチの効果 \\ 雷 玉平*・高橋英紀**・李 偉強* \\ (*中国科学院石家庄農業現代化研究所 \\ **北海道大学大学院地球環境科学研究科)}

要

コンクリートマルチが地温および土壌水分におよぼす 効果について, 中国河北省南皮県の中国科学院石家庄農 業現代化研究所南皮農業生態実験ステーションにおいて ナツメ（Ziziphus jujube Mill.）畑とライシメータを対 象にマルチ区と裸地区の比較観測を行った。観測内容は 地表面熱収支, 表面温度, 地中温度および土壤水分の垂 直分布である。ライシメータにおける比較試験によれば 1998 年 9 月の土壤蒸発量は裸地区の $1.74 \mathrm{~mm} \mathrm{day}^{-1}$ に 対しマルチ区では僅か $0.04 \mathrm{~mm} \mathrm{day}^{-1}$ であった。1998 年 12 月から 1999 年 2 月にかけての土裹凍結/融解期 におけるナッメ畑の表層 $10 \mathrm{~cm}$ の土壤水分はマルチ区 では $0.030 \mathrm{~g} \mathrm{~g}^{-1}$ 増加したのに対し, 裸地区では $0.032 \mathrm{~g}$
約

$\mathrm{g}^{-1}$ 減少した。9 月の熱収支観測によれば，マルチ区に おける日中の純放射量は裸地区より少なく, 深さ $5 \mathrm{~cm}$ の土壤水分も少ないにあかかわらず, 地中熱伝達量はマ ルチ区の方が裸地区より多かった。ライシメー夕区にお けるコンクリートマルチの表面温度は夏季には $57^{\circ} \mathrm{C} に$ 達し, 裸地地表面温度より約 $10^{\circ} \mathrm{C}$ 高かった。しかしそ の傾向はナツメ畑では緩和された。ライシメー夕区にお ける深さ $5 \mathrm{~cm}$ と $10 \mathrm{~cm}$ の夜間地温は夏季, 冬季を通じ て裸地区よりおよそ $2^{\circ} \mathrm{C}$ ほど高温であった。 キーワード: コンクリートマルチ, 土壤水分, 地温, 表面 熱収支, 表面温度 